\title{
Residual liquid from deep magma ocean crystallization in the source of komatiites from the ICDP drill core in the Barberton Greenstone Belt
}

\author{
MAUD BOYET ${ }^{1}$, MARION GARÇON ${ }^{2}$, NICHOLAS T. \\ ARNDT $^{3,4}$, RICHARD W. CARLSON ${ }^{5}$ AND ZOLTAN \\ $\mathrm{KONC}^{1}$ \\ ${ }^{1}$ Université Clermont Auvergne \\ ${ }^{2}$ CNRS - University Clermont Auvergne \\ ${ }^{3}$ University Grenoble Alpes \\ ${ }^{4}$ Universite de Grenoble \\ ${ }^{5}$ Carnegie Institution for Science \\ Presenting Author:maud.boyet@uca.fr
}

Komatiites are ultramafic volcanic rocks found mainly in Archean greenstone belts. They are derived from the deep mantle and therefore yield valuable information on part of the early mantle that is rarely accessible. Here we present new results on the ${ }^{146} \mathrm{Sm}^{-142} \mathrm{Nd}$ isotope systematics of Barberton komatiites from the $3.48 \mathrm{Ga}$ Komati Formation and mudstones, sandstones and cherts from overlying formations (3.42 to $3.23 \mathrm{Ga}$ ). The samples were recovered from core in the International Continental Drilling Program and were previously analyzed for ${ }^{147} \mathrm{Sm}-{ }^{143} \mathrm{Nd}$ and ${ }^{176} \mathrm{Lu}-{ }^{177} \mathrm{Hf}$ systematics $[1,2]$.

Seven komatiites and 15 sedimentary rocks were analyzed by Thermal Ionization Mass Spectrometry (Thermo Scientific Triton). Resolved negative $\mu^{142} \mathrm{Nd}$ values (up to $-7.7 \pm 2.8$ ) were identified in komatiites. No analytically resolvable ${ }^{142} \mathrm{Nd}$ anomalies were measured in sedimentary rocks.

Our new measurements are incorporated into a larger set of previously published data on Barberton komatiites to better understand the ${ }^{142,143} \mathrm{Nd}^{-176} \mathrm{Hf}$ isotope evolution of the mantle source of these rocks $[1,3,4]$. Negative $\mu^{142} \mathrm{Nd}$ values measured in komatiites point to a source with subchondritic $\mathrm{Sm} / \mathrm{Nd}$ ratio that formed during the Hadean. Komatiites with deficit in ${ }^{\mu 142} \mathrm{Nd}$ are all characterized by low $\mathrm{Hf} / \mathrm{Sm}$ ratios. Our calculations show that the ${ }^{142,143} \mathrm{Nd}-{ }^{176} \mathrm{Hf}$ isotope signatures and $\mathrm{Hf} / \mathrm{Sm}$ ratios cannot be produced by recycling into the komatiite source of detrital sediments like those sampled in the Barberton area. We propose a four-stage model for the formation of the analyzed komatiites. Negative $\mu^{142} \mathrm{Nd}$ and low $\mathrm{Hf} / \mathrm{Sm}$ ratios developed during the crystallization of a deep magma ocean soon after Earth accretion. The material that ultimately became the source of komatiites was a residual liquid produced by $50 \%$ crystallization leaving a bridgmanite/ferropericlase/Caperovskite cumulate. Komatiites from the nearby Schapenburg belt share similar chemical and isotopic signatures [4], supporting our model of fractionation in a deep magma ocean early in Earth history.

[1] Blichert-Toft et al. (2015) Am. Min. 100 ; [2] Garçon et al. (2017) GCA, 206 ; [3] Puchtel et al. (2013), GCA 108 ; [4] Puchtel et al. (2016) G3, 17. 